\title{
Innovation Management: The Need of a Model for Manufacturing Micro - Enterprises
}

\author{
DOI: 10.12776/QIP.V21I3.933 \\ Diana Katiuska Peña Ponce, Angie Fernández Lorenzo, \\ Raúl Ricardo Fernández Concepción
}

Published: 30 November 2017

\begin{abstract}
Purpose: Innovation is an important element in enterprise productivity. This study aims to carry out a conceptual analysis on the role of the process of innovation management in the development of manufacturing microenterprises in general.
\end{abstract}

Methodology/Approach: We analyse the main models that exist today, their main components and the possibility of being adapted to the small size of the Micro Small and Medium Enterprises (MSMEs) which contributes to achieve the development and adoption of an innovative culture under the current conditions of this productive sector in Ecuador.

Findings: We identified the complexity of applying innovation management models to any type of company because these models are not multifunctional and there are restrictions for their application.

Research Limitation/implication: The current models of innovation management are not adapted to the characteristics and size of the microenterprises, which becomes into difficulties to bring about fundamental changes in the areas of innovation, intuition or inspiration, and, it is necessary to take actions in this regard.

Originality/Value of paper: This document is based on the literature review of the process of innovation management. Through this analysis, the authors detected that the smaller companies have more difficulties to carry out innovations than the larger ones.

Category: Literature Review

Keywords: innovation; management; model; microenterprise 


\section{INTRODUCTION}

"Management implies the ability to operate on key dimensions of different systems and processes, modifying their states and their directions" (Albomaz and Fernández, 1997), with a clear intention: to generate, rescue, analyse, mature and take advantage of those ideas, which could constitute innovations and obtain a favourable margin of competitiveness for the actors involved.

From this perspective, this concept of management, applied to innovation, needs to be clarified on its meaning, for which, these management activities have been classified into three types: sporadic, intermittent and systemic (Morales, 2002).

Therefore, the concepts of management and innovation are closely related. (OECD and European Communities, 2005) in the Oslo Manual suggests that innovation is "the introduction of a new, or significantly improved, product (good or service), process, new marketing method or a new organizational method, in the internal practices of the company, the organization of the workplace or external relations". All of which is associated with the management definition of previously stated, and it denotes an interest of paradigm change in the action (Albomaz and Fernández, 1997).

Innovation is a key tool for organizations seeking to become world class or excellence leaders (Parada, 2012).

The management of innovation can lead to failure, so it is imperative to assess the risk involved (Baena, et al., 2009). Defined methodologies and strategies must be established in order to be able to innovate, as well as using tools to study the factors involved in the innovation process and detecting the opportunities and threats that exist in the different scenarios.

Innovation Management (IM) is, therefore, according to these authors, a principle or approach to management completely voluntary. It is not ruled by legislation, but its implementation can be structured through standards and non-binding models, that is to say, voluntary models.

Although there are no established formulas for the process of innovation, it is useful to consider necessary certain principles, to generate innovations from organizations such as stimulating disruptive thinking, acting with knowledge of the sources of innovation, performing technological surveillance, approaching to problems in an interdisciplinary way, generating spin-offs and creating networks to promote partnership.

In developed countries (DC) there is a large amount of data and empirical studies that show the innovative activities developed by firms and the adequate estimates of the results, thanks to those activities. It confirms the existence of the link between technological innovation and competitive performance - this is not the case of Latin America, where there are deep questions about the characteristics and scope of technological change processes. 
In Ecuador, MSMEs constitute an important sector of the economy. In 2014 there were 91,066 of them, 80\% higher than 2009 (INEC, 2016a) and on average they generate $60 \%$ of employment (Quiñonez, 2012).

Although there are many limitations to the management of innovation in SMEs today, a number of innovation management models have been developed for SMEs, and they cannot be adjusted to MSMEs because of their size, which increases the gap in their technological development.

The development of this sector demands science and innovation to raise the effectiveness of the business system. Hence, the need for a model that fits the characteristics of these companies, so that it can link scientific results, not only to implement them but also to allow a flow of business criteria that favour feedback for innovation adequacy.

This paper considers the theoretical bases of innovation management for microenterprises in the manufacturing sector, specifically the food sector in Ecuador.

\section{CONCEPTUAL ANALYSIS ON INNOVATION MANAGEMENT PROCESS AND INNOVATION MANAGEMENT MODELS}

\subsection{Management of Innovation}

Álvarez (2015) quoting Ospina (1993), and Ortiz and Pedroza (2006) mention that the concept of management arises to refer to a more audacious and heterodox way of managing with a more aggressive orientation than administration itself focused on the action and the creative solution of the administration problems within a context of innovation.

Faloh (2006) states that the new management paradigm, understood or not, means a phenomenon of innovation, not a process or product innovation, but a social innovation, and as such, it exercises its influence at all levels, going through the organizations and reaching the people who are part of it.

In a world where human needs are increasingly sophisticated and even complex, innovation has become the central element in the growth and development of societies and, with them, organizations understood as social entities oriented towards the fulfilment of objectives and designed as active systems (Sheperd, et al., 2012), deliberately structured and coordinated, linked to the external environment (Daft, Murphy and Willmott, 2010).

Thus, when talking about innovation, it means having a culture of opening to changes in the company (Marulanda, López and López, 2016), that is, that the members of the organization are willing to accept the adoption of innovation (Ayala, 2014). This happens because innovation is an eminently human mental process that underlies beyond the genetic condition and the cultural profile of people. Innovation is, therefore, an issue closely linked to the management of knowledge (Peña, 2003). 
Perhaps one of the most correct definitions is that of Schumpeter, for whom "innovation not only consists in new products and processes but also in new forms of organization, new markets and new sources of raw materials" (Berry and Taggart, 1994). Success in innovation is one of the main sources for companies to maintain and expand their markets.

For Huber (2001) successful IM begins when an inventive solution solves a market problem in the context of a company's strategy. The solution must be inventive because otherwise, competitors will copy it easily and quickly and so the competitive advantage will be lost.

From this perspective, the IM refers to a different way of achieving organizational synergy based on a planned change, on the use of human capital and the generation of organizational knowledge in favour of innovation, and it is shown as the result of four processes: knowledge creation, knowledge absorption, knowledge integration and knowledge reconfiguration (Bravo and Herrera, 2009).

Therefore, competitiveness is achieved through innovation. Each organization must adapt the process to its own possibilities of development and integration of knowledge, that is, to its own capacity for innovation (Bravo and Herrera, 2009), representing a path through which knowledge is transferred and becomes a process, a product or a service that incorporates new advantages for the market or for the society (Flormichella, 2005).

Organizations are based on the structured exchange of knowledge (individual and group) to respond to different problems, needs and claims of their stakeholders (Fernández, et al., 2017) and, therefore, it is not easy to speak of a unique model of innovation management in companies.

This implies emphasizing the importance of establishing reliable and durable communication channels both within the firm and with external agents (suppliers, clients, competitors, universities, research institutes, etc.) (Orjuela, 2011).

Likewise, the diffusion of innovations between the economic agents and the feedback that it provides, allows to improve the original innovation and increase the number of potential users. From this point of view, it can be said that isolation clearly conspires against the competitive development of firms, especially in relation to the innovation and organization of the productive process (Gómez, et al., 2016).

For that reason, innovation is considered today as one of the most important resources for the development of economies, creating new technologies and knowledge. It improves existing products and processes, adopts them from other economic units or creates new goods and services. 


\subsection{Models of Innovation Management}

For Miller and Morris (1999), who consider there are four generations of innovation, the first focuses on existing needs and is based on the knowledge possessed; the second is addressed through questions to the future needs of consumers and the new knowledge required; the third focuses on the development of technology portfolios linked to business and products for existing markets.

The ability to develop continuous and discontinuous innovation is called fourthgeneration research and development, based on knowledge, experiences and their implementation in different scenarios where technology has the function of support.

The effective innovation management of this generation requires a process that includes the context where it takes place, which is made up by the development of the market and the ability of the organization to respond. This competitive architecture defines the broader panorama of the organization of the market in which it competes, its customers, needs and demands, types of satisfiers, competing organizations, products in offer, characteristics, etc. (Tukker and Tischner, 2017).

The organization's ability to respond to these needs and demands is given by strategies, technology, processes, systems and tools, research and development of products and / or services where knowledge is applied, acquired and created.

Miller and Morris (1999) propose an innovation process that consists of four phases:

- Phase 1: It is the transformation of the initial idea into the conceptual definition of the application family;

- Phase 2: The improvement community takes responsibility for the project;

- Phase 3: Development of new products, services, families of distribution and development of methods;

- Phase 4: Development of market activities for a product family.

Another model of innovation is the one proposed by Utterback (2001), which has an engineering focus where technological and economic factors determine the viability of innovation. It proposes a model for the innovation process that consists of six stages: 1: Initiation of the process; 2: Formulation of the idea; 3 : Formulation of the problem; 4: Problem solution; 5: Improvement and development; and 6: Use and diffusion. 
The innovation process proposed by Utterback (2001) coincides with the one suggested by Miller and Morris. Regardless of the number of phases and stages that each one describes, three important moments are recognized in the process: firstly, need or idea is identified to be developed, and then the idea is developed and finally implemented and spread. All three moments require knowledge to be carried out.

According to Kim and Mauborgne (2004), if companies aspire to be successful with their innovations, they have to be based on three fundamental criteria: Utility for the buyer (is there a compelling reason to buy the product or the service offered?), strategic price (is it attractive, does it generate demand?), and a solid cost structure (can the company make money from its business model?). At the same time, they must prepare to overcome three possible obstacles:

- Employees, who might reject a new concept if it is seen as a threat to the availability of resources or change the power structures in the company.

- Consumers, who may not adopt a new idea because they do not understand its benefits or lack the necessary support infrastructure.

- Society, which will turn its back on innovation if it does not clearly understand the proposal or fears its consequences.

Gutiérrez and Núñez (2007) affirm that: "When companies face decisions that imply growing or innovating, leaders have to cope with the following dilemma: either to take advantage of their positive vision of opportunity and act as entrepreneurs, or to value risks and costs involved in this decision for short-term results, acting as financial directors." It is therefore, of particular importance to establish an ad hoc innovation management model for the needs of organizations, since there are several examples oriented to different types of organizations. It is also necessary to initiate actions aimed at making effective decisions for the dissemination of the new innovative culture.

It is complex to think of the existence of a multifunctional innovation management model; that is, that it could be applied without restrictions to any type of organization: public, social or private; micro, small, medium or large; service or manufacturing; family or corporate, and so on.

\section{INNOVATION MANAGEMENT IN SMALL AND MEDIUM ENTERPRISES IN THE INTERNATIONAL CONTEXT}

Not all companies have a performance and / or culture of innovation that allow them to respond to the changing needs of the market. MSMEs have structural characteristics that place them at a relative disadvantage to local and global competition, facing obstacles such as technological conversion (Vázquez, 2016). 
At present, global trends in the business sector recognize a fundamental segment of the economy in small and medium-sized enterprises (SMEs and MSMEs), which generates an adequate income factor for the regions (Orozco, et al., 2015). In this context, it is necessary to stimulate change and permanent innovation, at a speed that follows the dynamics of the variable market.

Therefore, SMEs have the challenge of recognizing that in today's market, for companies to be competitive, change is necessary, and consequently innovation must be permanent. More innovation is required in the management of the company, so that in order to survive and advance, SMEs are forced to respond quickly to innovation, or what is best to a culture of transformation.

In that regard, innovation is assumed as the way to convert ideas and knowledge into new products or improving the existing ones, which the market recognizes and values. Innovation implies a desire for a transformation that allows it to be more competitive. In any case, the ability to innovate in all scenarios ensures the survival of companies and in this particular case of SMEs, since the current global trends in the business sector recognize in small and medium enterprises (SMEs and MSMEs), a vital part of the economy of any country.

Therefore, regional advances and the arrival of imported products, force the SMEs to be in a permanent process of professionalization of their management and technological modernization to increase productivity and a strategic redefinition of the business, to put themselves in a specific market place.

MSMEs must take on the change and internalize the new paradigms, to reach a new way of thinking and acting. Thus, the ability to innovate in all spheres of business will ensure, at least, the survival of the organization, a non-sufficient condition in the current scenarios.

The industrial environment that currently characterizes the developed countries is fostering a strong concentration in the development or improvement of new products, and the challenge of the MSMEs specifically contributes to consider the global nature of their markets and the need to face the existing competitiveness (Hidalgo, León and Pavón, 2000).

It is important that companies dedicate greater efforts to innovation that allows them to increase or simply maintain their competitiveness. There are several factors and trends that increase this competitive pressure, such as the globalization of markets, the emergence of new competitors or the rapid evolution of technologies.

As a result, companies cannot remain static, but must focus their efforts on continuously improving and renewing their products, services and processes to compete adequately in markets that are increasingly demanding and dynamic; in other words, innovation becomes a mandatory requirement not only for growth but also for business survival. 
It is, therefore, necessary for companies to accept the challenge of innovation, which means that they must:

- Innovate frequently and effectively;

- See innovation as a way of being and acting, not an exception nor an activity that interferes with the proper functioning of the company.

From this perspective, it is necessary to recognize that a significant effort in product innovation (Valencia, 2015) has been taking place at the regional level, for some years, with some notable advances but with deficiencies that are becoming difficult to solve.

\section{INNOVATION MANAGEMENT PROCESS IN ECUADOR}

The presence of SMEs in the composition of the industrial fabric is prominent worldwide. This is evidenced with the support of the figures presented by (Fernández, 2005), in Europe; SMEs constitute 77\% of companies; in Germany, $99 \%$ of companies.

In 1993, in the present European Union, EU (formerly European Economic Community) there were 17 million SMEs; in the United States of America (USA), SMEs made up $95 \%$ of companies. As for Asia, Japan, they are made up of $99 \%$ of companies. Regarding Latin America, SMEs are 99\% in Mexico; in Argentina they correspond to $26.8 \%$ and in Mipymes $71.7 \%$; in Colombia they are $56.2 \%$ and MSMEs $30.9 \%$, according to data provided by the Productive Development and Business Division of ECLAC, on the official figures of each country (ECLAC, 2010).

This shows the high representation of SMEs in the economy of the nations, which is recognized into a social and economic relevance, since these companies contribute to the economy of the country, inserted into decisive sectors that generate high levels of occupation of the labour force. Likewise, they are contributors of exports, and investments by their incidence in the Gross Domestic Product per person (GDP/p).

In Ecuador, the consumption of food is of massive nature and the industry dedicated to the elaboration of food has a particular relevance within the national economic production and performance.

According to Garzón, et al. (2016), the value added of the manufacturing industry, excluding oil refining, remained in the period 2012-2016, above $11 \%$ of the Gross Domestic Product (GDP), with a participation of 4,67\% of the food and beverages industry in 2016 (CFN, 2016).

An important aspect to consider is that the food and beverage sector is a significant source of employment, if it is taken into consideration that in 2016 the employed personnel index grew by 5.5\% compared to 2015 (INEC, 2016b). 
In addition, the importance of the sector not only comes from the supply but also the consumption of food and non-alcoholic beverages is massive and within the structure of expenditure of households, it is the largest contributor. Therefore, it constitutes the fourth part of the increment of the consumer price index (CPI) basket, being the division with the highest share in inflation all along history (INEC, 2014).

All this activity gives rise to the impulse of a variety of businesses, among them micro-enterprises dedicated to the food sector, but in general these types of companies, have government support programs, but they have not been sufficient to generate significant changes that are oriented towards the adoption of an innovative culture and usually do not have a timely reach. Taking into consideration a particular case, it can be mentioned that as a tool for the promotion and development of SMEs, the National System to Support Entrepreneurship, EmprendEcuador, was created for SMEs that are already in the mature stage.

InnovaEcuador has been created as the mechanism for companies to have the opportunity to generate products based on new knowledge (innovations), to access other markets, improve their productivity and improve their exportable offer. It also favours the achievement of funds for the development of MSMEs, products offered by this same ministry as Exportapyme, which is a co-financing component of the Fondepyme Program (Fondepyme, 2013).

In this context, the MSMEs are underdeveloped in terms of generating new ideas, since technological innovations have always been at the origin of the changes in production processes. The incorporation of new techniques presumes changes in the production systems, which bring productivity increases and costs reductions, which, in turn, have a favourable impact on the demand commission. In this regard, the incorporation of new technologies allows improvements in transportation and communication systems, as well as higher levels of quality and variety in the supply of products and services (Albuquerque, 2004).

Smaller companies generally have fewer resources and are often lacking a specialized research and development (R\&D) department. They are finding it more difficult to carry out radical innovations on a continuous basis than larger companies, which have more resources, although there are some exceptions depending on the sector. In addition, the small size of the Mype companies does not allow them to take advantage of the big scale economies enjoyed by larger companies (Thom and Muller, 2013). Of course, the sphere of action of a company may differ greatly from one to another and thus foster different needs for innovation.

In spite of these multiple development programs for Ecuadorian enterprises, the progress made in this vital area for the development, expansion and permanence in the micro-enterprise market is still scarce in relation to the management of innovation. 
Therefore, it is necessary to continue supporting, with better mechanisms, the promotion of innovation in Ecuadorian companies as an alternative to increasing competitiveness, as well as to continue inquiring about the subject of innovation. Hence, it is necessary to carry out a study of the models that contribute with the innovative production of the MSMEs in the food sector, taking as reference the following question: Which are the models that influence the innovation of products in the food sector MSMEs?

Thus, when talking about the models that influence product innovation in SMEs, it will be possible to identify which of them are adequate to the requirements of MSMEs to design future scenarios for their development; that is to say, to design strategies in order to increase the innovation in products and then improve the business competitiveness of these companies.

It is evident that at the beginning of the 21st century, SMEs face new challenges, as the quality, speed and agility of their work, which nevertheless, will not be enough attributes to compete successfully. Then it becomes necessary to develop new skills, disregarding certain things and learning others.

This argument deserves to have a discourse where the positions really change the prevailing conceptions and allow the new manager to adapt, with the highest capacity of response and in intellectual conditions to think beyond the unimaginable (Ludovic, 1995; Castillo and Leal, 2010). The current scenarios are precise to leave behind old paradigms that hinder the ability to think, act, and learn new experiences, which translates into difficulties to bring about fundamental changes in the areas of innovation, intuition or inspiration.

\section{CONCLUSIONS}

The IM process for the micro-enterprise sector should be focused on their sustainability, being flexible, and adjusting to the size of these companies, creating new opportunities for expansion and growth. Under this premise, it is necessary that decision-makers at the national level become aware of the main obstacles that influence on the efficient development of this type of company.

In Ecuador, there are strengths that can allow an effective management of innovation in this type of companies that at present, constitute an important sector of their economy. These include:

- Universities that generate inventions for the business sector, which can be adaptable to the size of micro-enterprises.

- Current policies in the country that recognize the role of innovation and technological management for the country's development. 


\section{ACKNOWLEDGMENTS}

This paper was written with the support of the Southern State University of Manabí and the University of Pinar del Río.

\section{REFERENCES}

Albomaz, M. and Fernández, E., 1997. Indicadores en ciencia y tecnología: reencuentro de la política con la gestión. Innovación, competitividad y desarrollo sustentable, pp.2175-2190.

Albuquerque, F., 2004. El enfoque del desarrollo económico local. Buenos Aires: Organización Internacional del Trabajo.

Álvarez, R., 2015. Enfoque de innovación en las organizaciones. México: Centro de Producción Editorial.

Ayala, P., 2014. Cultura Organizacional e Innovación. Revista Gestión de las Personas y Tecnología, 7(19), pp.44-55.

Baena, C., Gutiérrez, L., Gutiérrez, E. and Trujillo, M., 2009. Guía para la autoevaluación de la gestión de la innovación empresarial. Andalucía: Centro Andaluz para la Excelencia en la Gestión/Instituto Andaluz de Tecnología.

Berry, M. and Taggart, J., 1994. Managing Technology and Innovation: a review. $R \& D$ Management, 24(4), pp.341-353.

Bravo, E. and Herrera, L., 2009. Capacidad de innovación y configuración de recursos organizativos. Intangible Capital, 5(3), pp.301-320.

Castillo, G. and Leal, B., 2010. Innovación en producto en las MPYMES del Fondo Emprender del sector de alimentos de la ciudad Manizales. Manizales: Universidad Autónoma de Manizales.

CFN, 2016. Ficha sectorial. Sector manufacturero. Alimentos preparados y bebidas. 2017. Quito: CFN.

Daft, R., Murphy, J. and Willmott, H., 2010. Organization Theory and Design. Singapur: CENGAGE Learning EMEA.

ECLAC, 2010. Desarrollo social de América Latina. Santiago de Chile: ECLAC.

Faloh, R., 2006. Gestión de la innovación Una visión actualizada para el contexto iberoamericano. La Habana: Editorial Academia.

Fernández, A. Emperatriz Arias Puedmag, D., Rocío Padilla Oyos, C., Calero Morales, S. and Aníbal Parra Cárdenas, H., 2017. Alianzas y conflictos entre grupos de interés de un hospital militar: aplicación del método MACTOR. Revista Cubana de Investigaciones Biomédicas, 36(1), p.12.

Fernández, E., 2005. Estrategia de innovación. Madrid: Ediciones Paraninfo. 
Flormichella, M., 2005. La evolución del concepto de innovación y su relación con el desarrollo. Buenos Aires: INTA.

FONDEPYME, 2013. Proyecto: Fomento de las Mipymes ecuatorianas. Actualización propuesta documento 2. Quito: Ministerio de Industrias y Productividad.

Garzón, N., Kulfas, M., Palacios, J. and Tamayo, D., 2016. Evolución del sector manufacturero ecuatoriano 2010-2013. Tipologías estáticas y dinámicas de las manufacturas. Quito: INEC.

Gómez, T. Zarazúa, J.A., Ramírez-Valverde, B., Guillén-Cuevas, L.A., and Rendón-Medel, R., 2016. Masa crítica y ambiente de innovación en el sistema productivo jitomate, Chiapas. Revista Mexicana de Ciencias Agrícolas, 15, pp.2949-2964.

Gutiérrez, I. and Núñez, M., 2007. El impacto de la gestión de la innovación radical en la sustitución del consejero-delegado: evidencia empírica en la industria española de periódicos. Cuadernos económicos de I.C.E., 73, pp.65-83.

Hidalgo, A., León, G. and Pavón, J., 2000. La gestión de la innovación y la tecnología en las organizaciones. Madrid: Pirámide.

Huber, J., 2001. Managing Innovation: mining for nuggets. Licoln: Autors Choice Press.

INEC, 2014. Inflación julio 2014. Quito: INEC.

INEC, 2016a. Sistema de indicadores de la producción. Quito: INEC.

INEC, 2016b. Panorama laboral y empresarial del Ecuador. Quito: INEC.

Kim, C. and Mauborgne, R., 2004. Value innovation: the strategic logic for high growth. Harvard Business Review, July-August, pp.1-12.

Ludovic, V., 1995. Iniciación de las PYMES en la posmodernidad. San Cristóbal: Editorial Táchira.

Marulanda, C., López, M. and López, F., 2016. La Cultura Organizacional y las Competencias para la Gestión del Conocimiento en las Pequeñas y Medianas Empresas (PYMEs) de Colombia. Información Tecnológica, 27(6), pp.3-10.

Miller, W. and Morris, L., 1999. 4th Generation R\&D. Managing Technology and Innovation. New York: John Wiley \& Sons.

Morales, M., 2002. La reforma del Estado y las nuevas orientaciones de la administración pública, a partir de evidencias en México. Lisboa: CLAD.

OECD and European Communities, 2005. Manual de Oslo, guía para la recogida e interpretación de datos sobre innovación. París: OECD/European Communities.

Orjuela, S., 2011. La comunicación en la gestión de la responsabilidad social empresarial. Correspondencias \& Análisis, 1, pp.137-156. 
Orozco, E., Bateman, C. and Torres, M., 2015. El estado y condiciones para el emprendimiento en las pequeñas y medianas empresas de Santa Marta, Colombia. Verbum, 10, pp.13-23.

Ortiz, S. and Pedroza, A., 2006. ¿Qué es la gestión de la innovación y de la tecnología (GINNT)?. Journal of Technology Management \& Innovation, 1(2), pp.64-82.

Ospina, S., 1993. Gestión, política pública y desarrollo social: hacia la profesionalización de la gestión pública. Gestión y Política Pública, II(1), pp.3556.

Parada, J., 2012. Creación de un nuevo ecosistema para la innovación en Nuevo León. Innovación y Competitividad, IX(46), p.23.

Peña, J., 2003. La innovación como un fenómeno evolutivo: implicaciones para la economía y las políticas públicas asociadas. Interciencia, 28(6), pp.353-361.

Quiñonez, M., 2012. Estudio de la gestión competitiva de las pequeñas y medianas empresas (PYMES) comerciales. Caso Esmeraldas, República del Ecuador. Observatorio Latinoamericano de la Economía, 175, p.11.

Sheperd, C., Ahmed, P., Ramos, L. and Ramos, C., 2012. Administración de la innovación. México: Pearson.

Thom, N. and Muller, R., 2013. Management de la innovación en las empresas pequeñas y medianas. Resultados de un estudio exploratorio. Madrid: IDOE.

Tukker, A. and Tischner, U., 2017. New Business for Old Europe: ProductService Development, Competitiveness and Sustainability. 2nd ed. New York: Routledge.

Utterback, J., 2001. Dinámica de la innovación tecnológica. Madrid: Fundación Cotec para la Innovación Tecnológica.

Valencia, M., 2015. Capacidades dinámicas, innovación de producto e aprendizaje organizacional en pymes del sector cárnico. Ingeniería industrial, 36(3), pp.297-305.

Vázquez, E., 2016. Evaluación de la adopción de tecnologías de información centrado en el beneficio, costo y riesgo para las pequeñas y medianas empresas del rubro de la construccíon en el Perú. Perú: Universidad Señor de Sipán.

\section{ABOUT AUTHORS}

Diana Katiuska Peña Ponce - Economist. Master in Enviroment Management (Universidad de Pinar del Río Hnos. Saíz Montes de Oca). PhD student of the Economic and Managerial Science Doctoral Program of Universidad de Pinar del Río, Cuba. Martí end Street 270, Pinar del Río, Pinar del Río, Cuba, e-mail: maymar811@hotmail.com. 
Angie Fernández Lorenzo - Bachelor in Economy. Doctor in Economic Sciences (Universidad de Pinar del Río, 2011). Professor of the Department of Economics, Management and Commerce Sciences, Universidad de las Fuerzas Armadas ESPE, Ecuador. Ave. Gral. Rumiñahui s/n, Rumiñahui, Pichincha, Ecuador, e-mail: aafernandez2@espe.edu.ec.

Raúl Ricardo Fernández Concepción - Chemical Engineer. Doctor in Technical Sciences (Universidad de Humboldt, 1987). Professor of the Forestry Studies Center, Universidad de Pinar del Río, Cuba. Martí end Street 270, Pinar del Río, Pinar del Río, Cuba, e-mail: raulricardo@upr.edu.cu.

(C) 2017 by the authors. Submitted for possible open access publication under the terms and conditions of the Creative Commons Attribution (CC-BY) license (http://creativecommons.org/licenses/by/4.0/). 